\title{
Worldwide genetic structure of albacore Thunnus alalunga revealed by microsatellite DNA markers
}

\author{
Iratxe Montes ${ }^{1}$, Mikel Iriondo ${ }^{1}$, Carmen Manzano ${ }^{1}$, Haritz Arrizabalaga ${ }^{2}$, \\ Elisa Jiménez ${ }^{3}$, Miguel Ángel Pardo ${ }^{3}$, Nicolas Goñi ${ }^{2}$, Carys Ann Davies ${ }^{4}$, \\ Andone Estonba ${ }^{1, *}$
}

\author{
${ }^{1}$ Department of Genetics, Physical Anthropology and Animal Physiology, Faculty of Science and Technology, \\ University of Basque Country (UPV/EHU), Leioa, Spain \\ ${ }^{2}$ AZTI Tecnalia, Marine Research Unit, Pasaia, Spain \\ ${ }^{3}$ AZTI Tecnalia, Food Research Unit, Derio, Spain \\ ${ }^{4}$ Commercial Fisheries Research Group, Department of Life Sciences, Galway Mayo Institute of Technology (GMIT), \\ Galway, Ireland
}

\begin{abstract}
One of the most common problems in fisheries is the definition of management units. Albacore Thunnus alalunga is an important species for commercial fisheries. Its population structure is still partially unknown; however, on the basis of fisheries data, tagging experiments, and morpho-ecological studies, 6 management units are currently accepted for this species. The main objective of this study was to define genetic entities within $T$. alalunga and to discuss the appropriateness of current management units. For this purpose, 13 microsatellite loci were applied to 551 albacore samples collected worldwide, and the population genetic structure was assessed. The most relevant differences between management and genetic units were that (1) Atlantic and Indian Ocean samples are genetically indistinguishable, and (2) possible differentiation exists within the Pacific Ocean and also within the Mediterranean Sea. Thus, this study provides genetic information to clarify albacore population delimitation, which is a key factor to reach the demanded sustainable management of this resource.
\end{abstract}

KEY WORDS: Albacore · Management units · Microsatellite DNA · SSRs · Population genetics · Conservation $\cdot$ Fisheries $\cdot$ Stock

\section{INTRODUCTION}

Albacore Thunnus alalunga is an epi- and mesopelagic oceanic tuna which supports important commercial fisheries (Santiago 2004). It is cosmopolitan, highly migratory, and widely distributed mostly in temperate waters between latitudes $45^{\circ} \mathrm{N}$ and $45^{\circ} \mathrm{S}$, including the Mediterranean Sea. Stocks of this species are currently overexploited, and there is an urgent need to improve its conservation and management efforts (Collette et al. 2011). For conservation purposes, marine organisms should be managed at the population level since the extent and dynamics of population structuring underlies resilience and sustainability (Carvalho et al. 2010). Therefore, an improvement of $T$. alalunga population structure assessment is necessary.

Based on fisheries distribution, identification of separate spawning areas, different estimated growth rate, morphological differences, and tagging experiments, the International Commission for the Conservation of Atlantic Tunas (ICCAT), the Indian Ocean Tuna Commission (IOTC), the Western and Central Pacific Fisheries Commission (WCPFC), and the InterAmerican Tropical Tuna Commission (IATTC) established 6 management units for this species, 1 per 
ocean and hemisphere: the North Atlantic, South Atlantic, Indian, North Pacific, South Pacific, and Mediterranean stocks. The level of consistency among these 6 management units with regard to the population genetic structure of this species is only partially known.

Genetic approaches are becoming increasingly important to pelagic fish management procedures, since they have demonstrated enough resolution to detect intra-oceanic variability (Chow et al. 2000). They have already provided relevant information for direct management in several marine pelagic fish species such as sailfish Istiophorus albicans (Graves \& McDowell 1995), swordfish Xiphias gladius (Chow \& Takeyama 2000), bigeye tuna Thunnus obesus (González et al. 2008), bluefin tuna T. thynnus (Riccioni et al. 2010), and albacore (Arrizabalaga et al. 2004).

Genetic studies of natural populations often use highly polymorphic microsatellite loci because of their high statistical power for population genetics (Brooker et al. 1994, O'Connell \& Wright 1997, Oleksiak 2010). Thus, nuclear-encoded DNA microsatellite markers could shed light on the genetic variability and population genetic structure of albacore, as it has been previously reported for other tuna species, such as bluefin (Riccioni et al. 2010) and bigeye tuna (González et al. 2008). Indeed, in albacore, Takagi et al. (2001) reported differentiation within and between the Pacific and Atlantic Oceans based on 4 microsatellite loci. Additionally, based on 12 microsatellite loci, Davies et al. (2011) described genetic differentiation within the Mediterranean Sea and between North Atlantic and South Pacific samples. Previous studies on the genetic structure of albacore populations used other types of markers, such as allozymes (Pujolar et al. 2003), mtDNA (Chow \& Ushiama 1995, Yeh et al. 1997, Viñas et al. 1999, 2004, Nakadate et al. 2005, Wu et al. 2009), and blood groups (Arrizabalaga et al. 2004). Taken together, these studies showed genetic differences between the North Pacific and Indian Oceans, but barely detected, heterogeneity within oceans (Chow \& Ushiama 1995, Nakadate et al. 2005), or even between North Atlantic and Mediterranean stocks (Viñas et al. 1999, Pujolar et al. 2003). In addition, no study to date has included samples from all of the management units.
The main objective of the present study was to assess the population genetic structure of Thunnus alalunga on a worldwide scale in order to identify the genetically defined stocks within the species and, based on these findings, discuss the appropriateness of current management units.

\section{MATERIALS AND METHODS}

\section{Samples}

Tissue samples of 551 albacore were collected between 2003 and 2009 (see Table S1 in the supplement at www.int-res.com/articles/suppl/m471p183 _supp.pdf), from the 6 defined stocks (Fig. 1). Samples were stored in $96 \%$ ethanol at $-20^{\circ} \mathrm{C}$ until DNA extraction. All samples were provided by AZTI Tecnalia with the exception of those from the Balearic and Adriatic Seas, which were provided by the Department of Life Sciences of the Galway Mayo Institute of Technology (GMIT).

\section{Genetic loci}

Thirteen microsatellite loci were included in this study. All of these were originally characterized in tuna species other than Thunnus alalunga. Four

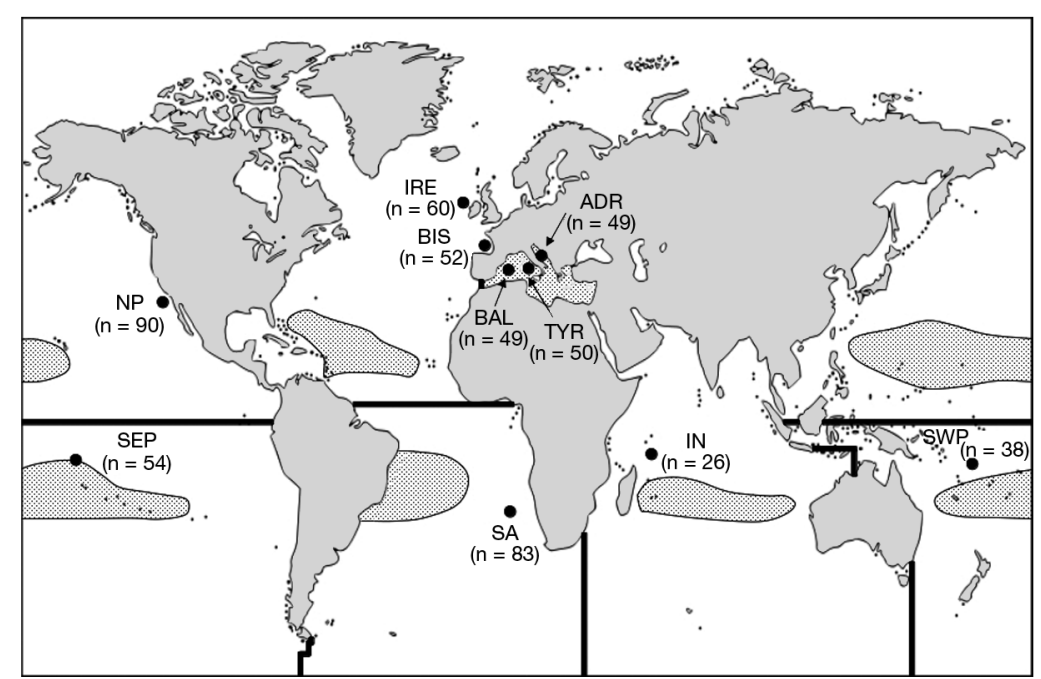

Fig. 1. Thunnus alalunga. Sampling locations (black dots), current stock boundaries (black lines), and albacore spawning areas (dotted areas). Information collected from Joseph et al. (1998). Abbreviations for sample locations: Adriatic Sea (ADR), Tyrrhenian Sea (TYR), Balearic Islands (BAL), Bay of Biscay (BIS), Celtic Sea (IRE), South Atlantic (SA), Indian Ocean (IN), North Pacific Ocean (NP), South-East Pacific Ocean (SEP), South-West Pacific Ocean (SWP) 
microsatellite loci were originally described in Pacific bluefin tuna T. orientalis: Ttho-1, Ttho-4, Ttho-6, and Ttho-7 (Takagi et al. 1999), and 9 microsatellite markers were originally characterized in Atlantic bluefin tuna T. thynnus: Tth-5, Tth-21 (McDowell et al. 2002), tth4, tth62, tth1-31, tth14, tth157, tth178, and tth226 (Clark et al. 2004).

\section{Laboratory analysis}

Genomic DNA was extracted from 50 to $75 \mathrm{mg}$ of muscle tissue for each individual using a Qiagen DNeasy 96 Blood and Tissue Kit. The amount and quality of DNA from each sample was subsequently quantified in a NanoDrop ND-1000 spectrophotometer (Thermo Fisher Scientific). The 13 microsatellite loci were amplified in 4 independent multiplex polymerase chain reactions (PCR). TUNAPLEX1 reaction contained 4 microsatellite loci (Ttho-1, Ttho-4, Ttho-6, and Ttho- 7 ; annealing temperature, $T_{\mathrm{a}}=52^{\circ} \mathrm{C}$ ), TUNAPLEX2 contained 2 loci (Tth-5 and Tth-21; $T_{\mathrm{a}}=$ $54^{\circ} \mathrm{C}$ ), TUNAPLEX3 contained 2 loci (tth 4 and tth62; $T_{\mathrm{a}}=60^{\circ} \mathrm{C}$ ), and TUNAPLEX4 contained 5 loci (tth1-31, tth14, tth157, tth178, and th226; $T_{\mathrm{a}}=57^{\circ} \mathrm{C}$; Table S2 in the supplement). All PCR reactions were carried out in a final volume of $10 \mu \mathrm{l}$ containing 7.5 to $20 \mathrm{ng}$ DNA, 1 to $1.5 \mathrm{mM} \mathrm{MgCl}_{2}, 0.2$ to $0.6 \mu \mathrm{M}$ of each primer, $1 \times$ buffer, 0.2 to $0.8 \mu \mathrm{M}$ dNTPs, and 0.5 to 2.5 units of AmpliTaq Gold DNA Polymerase (Applied Biosystems; Table S3). All multiplex PCRs were performed using the following conditions: $10 \mathrm{~min}$ initial denaturation at $95^{\circ} \mathrm{C}$, followed by 33 cycles of denaturation for $1 \mathrm{~min}$ at $95^{\circ} \mathrm{C}, 30 \mathrm{~s}$ at annealing temperature, and $1 \mathrm{~min}$ at $72^{\circ} \mathrm{C}$ for extension. An extra final extension for $10 \mathrm{~min}$ at $72^{\circ} \mathrm{C}$ was included after the last cycle. Two independent runs were performed in an ABI Prism 3100 Genetic Analyzer (Applied Biosystems): the first run for TUNAPLEX1 to -3 and the second for TUNAPLEX4 (Table S2). A 50 to 500 bp size standard (LIZ500) was used to determine allele size. Raw data were processed with GENESCAN 3.7 and analyzed with GENOTYPER 3.7 software (Applied Biosystems).

\section{Descriptive statistics}

In order to evaluate deficit or excess of heterozygotes within each sample, the $F_{\mathrm{IS}}$ statistic (Weir \& Cockerham 1984) was calculated using FSTAT v.2.9.3 (Goudet 2001). The Fisher exact test was used to test for departures from the expectations of HardyWeinberg equilibrium (HWE), as implemented using
GENEPOP v4.0 software (Rousset 2008). HWE was evaluated for each locus and each sample. FSTAT v.2.9.3 software (Goudet 2001) was used to estimate the mean number of alleles (MNA), allelic richness $(\mathrm{AR})$, observed heterozygosity $\left(H_{0}\right)$, and expected heterozygosity $\left(H_{\mathrm{e}}\right)$. The false discovery rate (FDR) procedure (Benjamini \& Hochberg 1995) was applied to correct the obtained HWE p-values. The presence and frequency of null alleles was estimated using the EM algorithm implemented in FreeNa (Chapuis \& Estoup 2007) for each locus and sample.

\section{Genetic population structure analyses}

The existence of population structure in the whole sample was revealed in the Bayesian model-based clustering algorithm implemented using STRUCTURE v2.3.3 software (Pritchard et al. 2000). We used the admixture model and the LOCPRIOR option, and the number of ancestral clusters, $\mathrm{k}$, was determined by comparing log-likelihood ratios in 10 runs for values of $\mathrm{k}$ between 1 and 10. Each run consisted of 10000 iterations with a burn-in period of 10000 . Best $\mathrm{k}$ was estimated as proposed by Pritchard et al. (2000). CLUMPP v1.1.2 software (Jakobsson \& Rosenberg 2007) was used to determine the optimal assignation of clusters for the analyzed individuals, maximizing similarity between the different structure replications. The resulting clusters were visualized using DISTRUCT v1.1 software (Rosenberg 2004).

All microsatellite loci were tested for natural selection using LOSITAN software (Antao et al. 2008). When using polymorphic DNA markers with high mutation rates, such as microsatellites, to analyze weakly genetically differentiated populations, as in the present case, the role of mutation in genetic data should be tested. To elucidate the role of mutation, the $R_{\mathrm{ST}}$ distribution ( $\mathrm{p} R_{\mathrm{ST}}$ ) with $95 \%$ confidence intervals (CIs; Hardy et al. 2003) was constructed using SPAGeDi v1.2 (Hardy \& Vekemans 2002).

To assess genetic diversity, pairwise $F_{\mathrm{ST}}$ (Weir \& Cockerham 1984) among albacore samples was performed using FSTAT v.2.9.3 software (Goudet 2001). Global corrected p-values for pairwise $F_{\mathrm{ST}}$ were obtained from FSTAT software. This software combines p-values of individual loci, weighting them according to their polymorphism level (Petit et al. 2001). A hierarchical analysis of molecular variance (AMOVA $;$ Excoffier et al. 1992) was used to partition the genetic variance between subsamples within groups $\left(F_{\mathrm{SC}}\right)$ and among groups $\left(F_{\mathrm{CT}}\right)$ using ARLEQUIN v3.0 (Excoffier et al. 2005). 


\section{RESULTS}

\section{Genetic diversity within populations}

Descriptive statistics across loci and samples, and for each microsatellite and sample are shown in Tables $1 \& 2$ and Table $\mathrm{S} 4$ in the supplement, respectively. $H_{\mathrm{e}}, \mathrm{AR}$, and MNA values were consistently high, similar to prevoius studies carried out with these markers in other species of the genus Thunnus (Takagi et al. 1999, McDowell et al. 2002, Clark et al. 2004). All loci proved to be highly polymorphic: between 5 and 33 alleles were detected per locus. tth14 was the least variable locus $(\mathrm{AR}=2.28)$ and $t$ th 14 was the most variable $(\mathrm{AR}=6.66$; Table 1$)$; for the analyzed samples, these values oscillated between 4.43 (South Atlantic, SA; see Fig. 1 for sample location codes) and 12.81 (North Pacific Ocean, NP; Table 2). All markers had high $H_{\mathrm{e}}( \pm \mathrm{SE})$ values ranging from
$0.54 \pm 0.05$ to $0.94 \pm 0.02$ (Table 1). Similarly high $H_{\mathrm{e}}$ values were found in all analyzed samples, with values ranging from $0.69 \pm 0.21$ to $0.75 \pm 0.19$ (Table 2). Significant departures from HWE proportions were found for several microsatellite loci and samples. The single locus test across samples to assess departure from HWE showed no significant $\mathrm{p}$-values for the Ttho-1, Ttho-7, tth14, tth157, and tth226 markers (Table 1). The samples from Balearic Islands (BAL), Bay of Biscay (BIS), SA, Indian Ocean (IN), NP, and South-East Pacific Ocean (SEP) had non-significant p-values for the Fisher exact test for HWE (Table 2). The frequency of null alleles was tested, and 4 of the 13 microsatellite loci (Ttho-6, Tth-5, tth62 and tth178) exhibited null allele frequencies higher than 0.05 , which was considered the threshold value for the presence of null alleles. $F_{\mathrm{IS}}$ values for those 4 markers ranged from 0.16 to 0.60 , whereas these values for the remaining 9 markers were low, between -0.06

Table 1. Thunnus alalunga. Descriptive statistics for the 13 microsatellite loci over all albacore samples analyzed. Number of genotyped individuals (n), allele number (k), mean number of alleles (MNA), allelic richness (AR), mean observed heterozygosity $\left(H_{0}\right)$, mean expected heterozygosity $\left(H_{\mathrm{e}}\right)$, Hardy-Weinberg equilibrium p-values (HWE), $F_{\mathrm{IS}}$ statistic, mean null alleles frequencies. Mean values are \pm SE. ${ }^{*}$ Significant $p$-values after false discovery rate correction (Benjamini \& Hochberg 1995 )

\begin{tabular}{|c|c|c|c|c|c|c|c|c|c|}
\hline Marker & $\mathrm{n}$ & $\mathrm{k}$ & MNA & $\mathrm{AR}$ & $H_{\mathrm{o}}$ & $H_{\mathrm{e}}$ & HWE & $F_{\mathrm{IS}}$ & Null \\
\hline Tth-21 & 448 & 5 & $3.0 \pm 0.8$ & 2.45 & $0.55 \pm 0.09$ & $0.54 \pm 0.05$ & $0.0050^{*}$ & -0.06 & $0.01 \pm 0.02$ \\
\hline Ttho-1 & 297 & 9 & $6.0 \pm 1.7$ & 3.33 & $0.60 \pm 0.18$ & $0.62 \pm 0.14$ & 0.0396 & 0.07 & $0.02 \pm 0.04$ \\
\hline Ttho-4 & 329 & 32 & $15.0 \pm 3.5$ & 5.69 & $0.78 \pm 0.07$ & $0.88 \pm 0.05$ & $0.0050^{*}$ & 0.06 & $0.03 \pm 0.04$ \\
\hline Ttho-7 & 292 & 19 & $11.0 \pm 4.4$ & 5.54 & $0.81 \pm 0.10$ & $0.86 \pm 0.07$ & 0.0349 & 0.04 & $0.02 \pm 0.03$ \\
\hline tth1-31 & 524 & 16 & $11.0 \pm 1.9$ & 4.42 & $0.73 \pm 0.09$ & $0.77 \pm 0.02$ & $<0.0001^{*}$ & 0.06 & $0.04 \pm 0.04$ \\
\hline tth14 & 521 & 9 & $5.0 \pm 1.4$ & 2.28 & $0.62 \pm 0.07$ & $0.61 \pm 0.04$ & 0.0503 & -0.01 & $0.01 \pm 0.02$ \\
\hline tth157 & 535 & 8 & $6.0 \pm 0.7$ & 3.10 & $0.61 \pm 0.06$ & $0.58 \pm 0.04$ & 0.0135 & -0.06 & $0.00 \pm 0.01$ \\
\hline tth226 & 529 & 27 & $17.5 \pm 1.9$ & 6.26 & $0.91 \pm 0.05$ & $0.92 \pm 0.02$ & 0.0529 & 0.02 & $0.01 \pm 0.01$ \\
\hline tth4 & 370 & 33 & $21.0 \pm 5.2$ & 6.66 & $0.90 \pm 0.08$ & $0.94 \pm 0.02$ & $<0.0001^{*}$ & 0.03 & $0.02 \pm 0.02$ \\
\hline Ttho-6 & 270 & 16 & $8.5 \pm 2.0$ & 4.15 & $0.59 \pm 0.22$ & $0.76 \pm 0.09$ & $<0.0001^{*}$ & 0.23 & $0.11 \pm 0.10$ \\
\hline Tth-5 & 473 & 24 & $17.0 \pm 2.6$ & 5.73 & $0.68 \pm 0.19$ & $0.88 \pm 0.04$ & $<0.0001^{*}$ & 0.25 & $0.11 \pm 0.09$ \\
\hline tth62 & 265 & 14 & $6.5 \pm 2.5$ & 4.09 & $0.24 \pm 0.16$ & $0.74 \pm 0.08$ & $<0.0001^{*}$ & 0.60 & $0.25 \pm 0.10$ \\
\hline th 178 & 506 & 17 & $11.0 \pm 2.0$ & 5.06 & $0.70 \pm 0.06$ & $0.83 \pm 0.02$ & $<0.0001^{*}$ & 0.16 & $0.06 \pm 0.03$ \\
\hline
\end{tabular}

Table 2. Thunnus alalunga. Descriptive statistics for 10 albacore samples over 9 microsatellite loci without null alleles. Number of genotyped individuals (n), mean number of alleles (MNA), allelic richness (AR), mean observed heterozygosity $\left(H_{0}\right)$, mean expected heterozygosity $\left(H_{\mathrm{e}}\right)$, Hardy-Weinberg equilibrium p-values (HWE), $F_{\text {IS }}$ statistic. Mean values are \pm SE. Sample abbreviations as in Fig. 1. ${ }^{*}$ Significant p-values after false discovery rate correction (Benjamini \& Hochberg 1995)

\begin{tabular}{|c|c|c|c|c|c|c|c|}
\hline Sample & $\mathrm{n}$ & MNA & $\mathrm{AR}$ & $H_{\mathrm{o}}$ & $H_{\mathrm{e}}$ & HWE & $F_{\mathrm{IS}}$ \\
\hline ADR & 49 & $9.44 \pm 6.88$ & 6.02 & $0.67 \pm 0.24$ & $0.69 \pm 0.21$ & $0.0056^{*}$ & 0.04 \\
\hline TYR & 50 & $10.11 \pm 5.58$ & 9.42 & $0.72 \pm 0.19$ & $0.73 \pm 0.18$ & $0.0056^{*}$ & 0.01 \\
\hline BAL & 49 & $10.89 \pm 5.58$ & 10.67 & $0.72 \pm 0.16$ & $0.75 \pm 0.14$ & 0.0348 & 0.04 \\
\hline BIS & 52 & $12.22 \pm 7.36$ & 11.04 & $0.71 \pm 0.13$ & $0.75 \pm 0.17$ & 0.0556 & 0.04 \\
\hline IRE & 60 & $10.00 \pm 6.86$ & 5.16 & $0.72 \pm 0.20$ & $0.75 \pm 0.19$ & $0.0001^{*}$ & 0.04 \\
\hline SA & 83 & $9.22 \pm 6.06$ & 4.43 & $0.71 \pm 0.15$ & $0.73 \pm 0.17$ & 0.0529 & 0.04 \\
\hline IN & 26 & $10.56 \pm 7.11$ & 10.30 & $0.72 \pm 0.19$ & $0.72 \pm 0.18$ & 0.0557 & 0.01 \\
\hline NP & 90 & $13.33 \pm 7.53$ & 12.81 & $0.75 \pm 0.17$ & $0.74 \pm 0.17$ & 0.0135 & 0.00 \\
\hline SEP & 54 & $11.56 \pm 7.07$ & 11.22 & $0.73 \pm 0.13$ & $0.75 \pm 0.16$ & 0.0396 & 0.02 \\
\hline SWP & 38 & $10.44 \pm 5.57$ & 10.01 & $0.73 \pm 0.09$ & $0.75 \pm 0.15$ & $0.0001^{*}$ & 0.02 \\
\hline
\end{tabular}


and 0.07 . $F_{\mathrm{IS}}$ values for the samples oscillated between 0.00 and 0.04 .

\section{Genetic diversity between populations: population genetic structure}

Due to the presence of null alleles, 4 microsatellite loci (Ttho-6, Tth-5, tth62, and tth178) were eliminated from subsequent analyses. STRUCTURE analysis evidenced population structure, with $\mathrm{k}=3$ (see Fig. $\mathrm{S} 1$ in the supplement at www.int-res.com/articles/suppl/ m471p183_supp.pdf) being the most likely number of clusters (Fig. 2): the Mediterranean group, the IndoAtlantic cluster, and the Pacific cluster.

Natural selection was examined for the 9 microsatellite markers. The Beaumont-Nichols test suggested directional natural selection at 1 microsatellite locus (Ttho-7). A BLAST search revealed that this locus was highly similar (e-value $=2 \times 10^{-4}, 78 \%$ similarity) to cpu-UA/3 MHC class I antigen gene (Genbank accession number AY008848.2) from the teleost fish Ictalurus punctatus (Antao et al. 2001). This marker was removed from further analyses since $F_{\mathrm{ST}}$ was calculated with neutral markers, in order to detect aspects of migration and drift that might otherwise be obscured by effects of selection. Removing this marker lead to a change in the number of populations from $\mathrm{k}=3$ to $\mathrm{k}=2 ; 1$ group consists of Mediterranean samples and the remaining samples were included in the other group (results not shown). Consequently, the Ttho-7 marker likely differentiates the South Pacific from the Indo-Atlantic group at the level of STRUCTURE analysis.

The overall multilocus $R_{\mathrm{ST}}$ value $\left(R_{\mathrm{ST}}=0.023\right) \mathrm{did}$ not exceed the $95 \%$ CI of $\mathrm{p} R_{S T}$ values $\left(\mathrm{p} R_{S T}=0.009\right.$; CI: -0.001 to 0.024 ), and therefore was not significant $\left(\mathrm{p}=0.060\right.$; Table S5 in the supplement). Pairwise $F_{\mathrm{ST}}$ values ranged from -0.007 (SA versus South-West Pacific Ocean, SWP) to 0.026 (Adriatic Sea, ADR versus NP and ADR versus SEP). Interestingly, in the Mediterranean Sea, the differentiation observed between $\mathrm{ADR}$ and BAL was significant $\left(F_{\mathrm{ST}}=0.012 \pm 0.012 ; \mathrm{p}=\right.$ 0.005). We did not detect significant differences between the samples from the Atlantic and Indian Oceans (BIS, Celtic Sea, IRE and SA versus IN), nor between Pacific Ocean samples (all pairwise comparisons using NP, SEP and SWP; Table 3).

Similar results were obtained using AMOVA analysis. All possible combinations of populations were tested, grouping the populations in levels from 3 to 5 groups. Results for a minimal $F_{\mathrm{SC}} / F_{\mathrm{CT}}$ ratio (least variance within and highest between groups) for each grouping level are shown in Table 4. In the 3cluster option, the best combination of populations was coincident with the STRUCTURE results. The 5-cluster option showed the lowest $F_{\mathrm{SC}} / F_{\mathrm{CT}}$ ratio, composed of (1) East Mediterranean Sea

Table 3. Thunnus alalunga. Pairwise $F_{\mathrm{ST}}$ values (below the diagonal) and p-values (above the diagonal) among samples. Sample abbreviations as in Fig. $1 .{ }^{*} \mathrm{p}<0.05$

\begin{tabular}{|lccccccccccc}
\hline Sample & ADR & TYR & BAL & BIS & IRE & SA & IN & NP & SEP & SWP \\
\hline ADR & - & 0.381 & $0.005^{*}$ & $0.006^{*}$ & $0.027^{*}$ & 0.103 & $0.011^{*}$ & $0.000^{*}$ & $0.000^{*}$ & $0.002^{*}$ \\
TYR & 0.000 & - & 0.269 & $0.024^{*}$ & 0.072 & 0.469 & $0.011^{*}$ & $0.000^{*}$ & $0.000^{*}$ & $0.002^{*}$ \\
BAL & $0.012^{*}$ & 0.001 & - & $0.006^{*}$ & 0.056 & 0.329 & $0.003^{*}$ & $0.000^{*}$ & $0.011^{*}$ & $0.003^{*}$ \\
BIS & $0.011^{*}$ & $0.006^{*}$ & $0.009^{*}$ & - & 0.503 & 0.689 & 0.431 & $0.006^{*}$ & $0.013^{*}$ & 0.165 \\
IRE & $0.011^{*}$ & 0.009 & 0.010 & -0.001 & - & 0.282 & 0.617 & 0.131 & 0.074 & 0.102 \\
SA & 0.008 & 0.000 & 0.002 & -0.004 & 0.004 & - & 0.463 & 0.266 & 0.327 & 0.833 \\
IN & $0.012^{*}$ & $0.012^{*}$ & $0.014^{*}$ & 0.000 & -0.002 & 0.000 & - & 0.214 & $0.029^{*}$ & 0.094 \\
NP & $0.026^{*}$ & $0.018^{*}$ & $0.011^{*}$ & $0.007^{*}$ & 0.006 & 0.003 & 0.002 & - & 0.550 & 0.083 \\
SEP & $0.026^{*}$ & $0.017^{*}$ & $0.007^{*}$ & $0.008^{*}$ & 0.009 & 0.002 & $0.008^{*}$ & 0.000 & - & 0.175 \\
SWP & $0.015^{*}$ & $0.014^{*}$ & $0.011^{*}$ & 0.003 & 0.008 & -0.007 & 0.007 & 0.004 & 0.003 & - \\
\hline
\end{tabular}


Table 4. Thunnus alalunga. Hierarchical analysis of molecular variance. Number of groups, grouped populations (indicated by brackets), notes about each grouping, and fixation indices: $F_{\mathrm{ST}}$ (variance among populations relative to the total variance), $F_{\mathrm{SC}}$ (variance among populations within groups), and $F_{\mathrm{CT}}$ (variance among groups relative to the total variance). Sample abbreviations as in Fig. $1 .{ }^{*} \mathrm{p}<0.05$

\begin{tabular}{|c|c|c|c|c|c|c|}
\hline $\begin{array}{l}\text { No. } \\
\text { groups }\end{array}$ & Sample & $F_{\mathrm{ST}}$ & $F_{\mathrm{SC}}$ & $F_{\mathrm{CT}}$ & $F_{\mathrm{SC}} / F_{\mathrm{CT}}$ & Notes \\
\hline 6 & $\begin{array}{l}\text { (ADR, TYR, BAL) (BIS, IRE) (SA) } \\
\text { (IN) (NP) (SEP, SWP) }\end{array}$ & $0.00839^{*}$ & 0.00335 & 0.00504 & 0.66100 & 6 stocks \\
\hline 5 & $\begin{array}{l}\text { (ADR, TYR) (BAL) (BIS, IRE, SA, IN) } \\
\text { (NP, SEP) (SWP) }\end{array}$ & $0.00931^{*}$ & 0.00000 & $0.00954^{*}$ & 0.00000 & Best 5 groups \\
\hline 4 & $\begin{array}{l}\text { (ADR, TYR) (BAL) (BIS, IRE, SA, IN) } \\
(\mathrm{NP}, \mathrm{SEP}, \mathrm{SEP})\end{array}$ & $0.00974^{*}$ & 0.00069 & $0.00905^{*}$ & 0.07300 & Best 4 groups \\
\hline 3 & $\begin{array}{l}\text { (ADR, TYR, BAL) (BIS, IRE, SA, IN) } \\
\text { (NP, SEP, SWP) }\end{array}$ & $0.00983^{*}$ & 0.00205 & $0.00778^{*}$ & 0.25800 & $\begin{array}{l}\text { STRUCTURE output } \\
\text { and best } 3 \text { groups }\end{array}$ \\
\hline
\end{tabular}

samples, (2) a Balearic sample, (3) Atlantic and Indian samples, (4) North and Southeast Pacific samples, and (5) Southwestern Pacific samples. It is associated with the highest (and significant) differences among groups $\left(F_{\mathrm{CT}}=0.00954\right)$, and the lowest differences among geographic samples within groups $\left(F_{\mathrm{SC}}=\right.$ $0.00000)$. Nevertheless, using only our best 5 microsatellites (those with $>80 \%$ scoring success), the pairwise $F_{\mathrm{ST}}$ values were lower (Table S6 in the supplement), and the $F_{\mathrm{SC}}$ value in AMOVA analysis was already 0 in the 3 -cluster option.

\section{DISCUSSION}

Information about population genetic structure is critical for the optimal conservation of marine biological communities. In this study, we assessed the population genetic structure of albacore Thunnus alalunga. A total of 551 individuals from all current management units of albacore were genotyped for 13 microsatellite loci. Currently established management units for this species exhibit clear mismatches and discrepancies with genetic population structure. We found that (1) Atlantic and Indian Ocean samples were homogeneous, and (2) a possible differentiation exists within the Pacific Ocean and also within the Mediterranean Sea.

DNA markers applied to a worldwide sample of albacore showed that some management units could be included in a single genetic unit (Atlantic and Indian Oceans, and North Pacific Ocean and Southeast Pacific). On the other hand, it appears that at least 2 genetic groups of albacore are currently managed as one in the Mediterranean Sea (East and West). Genetic diversity within species, due to local adaptation or stochastic differentiation, should be taken into account for the optimal management and conservation of the species. Therefore, a closer look at the genetic structure of albacore populations in the Mediterranean Sea and in the Pacific Ocean is advised; since this is the first study to investigate the worldwide population genetic structure of albacore, by analyzing albacore samples from all of the stocks defined for this species.

\section{Genetic diversity within populations}

Overall, marine species display high intra-population levels of genetic diversity and weak genetic differentiation among populations (DeWoody \& Avise 2000, Nielsen et al. 2009, Knutsen et al. 2011). In the present study, high values for allelic diversity $(\mathrm{AR}=$ 4.43 to $12.81 ; H_{\mathrm{e}}=0.69$ to 0.75 ) were observed in samples from all studied locations. These values are similar to those previously reported for bluefin tuna (Thunnus thynnus and T. orientalis: Carlsson et al. 2004, $\mathrm{AR}=5.33$ to $5.63, H_{\mathrm{e}}=0.66$ to 0.70 ; Carlsson et al. 2007: $H_{\mathrm{e}}=0.65$ to 0.66 ; Riccioni et al. 2010: $\mathrm{AR}=$ 8.5-10.0, $H_{\mathrm{e}}=0.70$ to 0.76 ) and albacore (Takagi et al. 2001: $H_{\mathrm{e}}=0.65$ to 0.86$)$, and they are consistent with the average value for marine fishes (DeWoody \& Avise 2000: $H_{\mathrm{e}}=0.66 \pm 0.22$ ). Furthermore, $F_{\text {IS }}$ values obtained for albacore $\left(F_{\text {IS }}=0.00\right.$ to 0.04$)$ are within the range of values reported for $T$. thynnus (Riccioni et al. 2010: $F_{\text {IS }}=-0.05$ to 0.09 ).

\section{Genetic diversity between populations: population genetic structure}

Our data support the existence of population structure within Thunnus alalunga, probably due to gen- 
etic drift and not mutation, as the $R_{\mathrm{ST}}$ test result was non-significant as opposed to the $F_{\mathrm{ST}}$ pairwise comparisons, which identified weak, but significant differences. The low levels of genetic differentiation reported for albacore have previously been ascribed to their biology, such as reproduction in the open ocean, their highly migratory nature, and/or large effective population sizes (Durand et al. 2005, Poulsen et al. 2006).

With regard to the genetic delimitation of albacore populations, different statistical methods yielded different results on the number of inferred populations. First, STRUCTURE software detected 3 albacore genetic groups $(\mathrm{k}=3)$ : (1) the Mediterranean group, (2) the Indo-Atlantic group, and (3) the Pacific group. Second, pairwise $F_{\mathrm{ST}}$ analysis suggested the existence of a subdivision within the Mediterranean Sea: Tyrrhenian and Adriatic Sea samples were grouped together and could be differentiated from the Balearic Sea. Third, AMOVA analysis indicated another subdivision within the Pacific Ocean. Different sensitivity of the statistics might explain this lack of coincidence in the number of populations recovered, but they are likely showing different hierarchical levels of grouping within the species.

Thus, the STRUCTURE analysis would only recognize the more basal clustering (Mediterranean, IndoAtlantic, and Pacific clusters), whereas $F_{\mathrm{ST}}$ and AMOVA would detect more contemporary aspects of population structure: those found within the Mediterranean Sea (East versus West), and those within the Pacific Ocean, where the Southwest Pacific might be differentiated from the rest.

The genetic relationship between North Atlantic and Mediterranean Sea albacore populations has been the subject of much debate. While initial studies did not find differences, probably due to the small sample size used by Viñas et al. (1999) or the lack of resolution of allozyme markers in the study by Pujolar et al. (2003), genetic differences were detected using other types of genetic markers such as blood groups (Arrizabalaga et al. 2004) and mtDNA (Viñas et al. 2004, Nakadate et al. 2005). In the present study, Mediterranean samples showed the highest and most significant $F_{\mathrm{ST}}$ values when compared to the oceanic ones (pairwise comparisons). This was also supported by STRUCTURE analysis $(k=2)$, which distinguished the Mediterranean Sea population from the rest. These results are consistent with the Mediterranean Sea populations of albacore being the ones with the smallest gene flow to or from other populations, suggesting an isolation event leading to their differentiation by genetic drift. In fact, com- pared to other albacore populations, the Mediterranean albacore show the most specific traits: smaller maximum length (Megalofonou 2000), lower trophic level (Goñi et al. 2011), and earlier maturity (ICCAT 2010), likely resulting from a local adaptation to living in a relatively small area, compared to oceanic albacore. Tagging data have revealed low migration out of the Mediterranean during the last decades (Arrizabalaga et al. 2004), so it is likely that compared to oceanic albacore, migrations within the Mediterranean Sea require less energy, which, in turn, could be invested in reproduction at earlier ages. Small size was also hypothesized to be an adaptation to hotter temperatures, as it favors heat loss (Bard 1981).

Moreover, our study suggests the existence of population structure within the Mediterranean Sea, which might reflect 2 genetically defined units: the western (the Balearic Sea sample) and the centraleastern (Tyrrhenian and Adriatic) population, which is consistent with Davies et al. (2011). Although there are no pronounced oceanographic barriers which might limit gene flow among populations in the Mediterranean Sea, differentiation between Eastern and Western Mediterranean areas has also been reported for the congeneric bluefin tuna Thunnus thynnus (Carlsson et al. 2004, Riccioni et al. 2010) using mtDNA and/or microsatellite data. All of these results suggest that at least 2 distinct albacore spawning areas may exist in the Mediterranean, although there is only a single one described (ICCAT 2010; Fig. 1).

In contrast to the genetic differentiation observed in the Mediterranean Sea, the Atlantic Ocean and Indian Ocean samples behave as a single genetic group. Previous studies using mtDNA (Yeh et al. 1997) as well as blood groups (Arrizabalaga et al. 2004) reported differences between them, although Arrizabalaga et al. (2004) suggested genetic proximity. Based on catch statistics, Morita (1977) suggested migration of albacore between these 2 oceans off South Africa, which could be promoted by the strong Agulhas Current. The same phenomenon was also suggested by González et al. (2008) in the congeneric bigeye tuna Thunus obesus. Thus, the observed genetic homogeneity between South Atlantic and Indian Oceans might be regarded as evidence of effective migration between South Atlantic and Indian albacore populations. Nevertheless, a more exhaustive study of these regions should be carried out, enlarging sample sizes and including new samples from the eastern region of the Indian Ocean and the western Atlantic. 
Finally, the genetic structure of albacore in the Pacific Ocean appears to be more complex than presently recognized in terms of the division of stocks. Using microsatellite markers, Takagi et al. (2001) described significant differences between the 2 Pacific hemisphere samples, as well as between Southwest and Southeast Pacific albacore. Our results failed to detect differences between North and South Pacific albacore, as did Chow \& Ushiama (1995) using mtDNA, but they suggested genetic heterogeneity within South Pacific albacore.

\section{Prospective analyses}

None of the individuals included in the present study were young of the year (YOY). Therefore, given the highly migratory nature of albacore, they could originate from a large number of potential spawning grounds. Future studies could benefit from including eggs, larvae, and/or young of the year. As such, genetic differences should reflect the spawning areas of the species, as some homing behavior is expected (Fonteneau \& Soubrier 1996), providing a genetic reference that is more consistent with the 6 stocks assummed for management purposes (Fig. 1).

Acknowledgements. We are indebted to F. Rendo and the Sequencing and Genotyping Service of the University of the Basque Country, UPV/EHU (Servicios Generales de Investigación) for their technical assistance, as well as to J. Areso, D. Fuller, K. Schaefer, V. Allain, S.Y. Yeh, D. Brophy, I. Fraile, and I. Arregi for sampling assistance. This work was supported by FOODBASK (IE10-289-FOODBASKII), ATM2010Hegaluze (351BI20090047), and ATM2008Bonorte (ACM2008BONORTE) projects funded by the Basque Government, and a Research Grant (no. 3571/2008) from the Researching Vice-Rectorate of the University of the Basque Country (UPV/EHU).

\section{LITERATURE CITED}

Antao AB, Wilson M, Wang J, Bengtén E, Miller NW, Clem LW, Chinchar VG (2001) Genomic organization and differential expression of channel catfish MHC class I genes. Dev Comp Immunol 25:579-595

Antao T, Lopes A, Lopes RJ, Beja-Pereira A, Luikart G (2008) LOSITAN: a workbench to detect molecular adaptation based on a $F_{\mathrm{ST}}$-outlier method. BMC Bioinformatics 9:323-327

Arrizabalaga H, Costas E, Juste J, González-Garcés A, Nieto B, López-Rodas V (2004) Population structure of albacore Thunnus alalunga inferred from blood groups and tagrecapture analyses. Mar Ecol Prog Ser 282:245-252

Bard FX (1981) Le thon germon (Thunnus alalunga Bonaterre 1788) de l'Océan Atlantique. De la dynamique des populations à la stratégie démographique. $\mathrm{PhD}$ thesis, Université Paris
Benjamini Y, Hochberg Y (1995) Controlling the false discovery rate: a practical and powerful approach to multiple testing. J R Stat Soc B 57:289-300

> Brooker AL, Cook D, Bentzen P, Wright JR, Doyle RW (1994) Organization of microsatellites differs between mammals and cold-water teleost fishes. Can J Fish Aquat Sci 51:1959-1966

Carlsson J, McDowell JR, Díaz-Jaimes P, Carlsson JEL, Boles SB, Gold JR, Graves JE (2004) Microsatellite and mitochondrial DNA analyses of Atlantic bluefin tuna (Thunnus thynnus thynnus) population structure in the Mediterranean Sea. Mol Ecol 13:3345-3356

> Carlsson J, McDowell JR, Carlsson JEL, Graves JE (2007) Genetic identity of YOY bluefin tuna from the eastern and western Atlantic spawning areas. J Hered 98:23-28

Carvalho GR, Creer S, Allen M, Costa FO and others (2010) Genomics in the discovery and monitoring of marine biodiversity. In: Cock JM, Tessmar-Raible $\mathrm{K}$, Boyen C, Viard, F (eds) An introduction to marine genomics. Springer, Dordrecht, p 1-32

Chapuis MP, Estoup A (2007) Microsatellite null alleles and estimation of population differentiation. Mol Biol Evol 24: 621-631

Chow S, Takeyama H (2000) Nuclear and mitochondrial DNA analyses reveal four genetically separated breeding units of the swordfish (Xiphias gladius). J Fish Biol 56:1087-1098

> Chow S, Ushiama H (1995) Global population structure of albacore (Thunnus alalunga) inferred by RFLP analysis of the mitochondrial ATPase gene. Mar Biol 123:39-45

Chow S, Okamoto H, Miyabe N, Hiramatsu K, Barut N (2000) Genetic divergence between Atlantic and IndoPacific stocks of bigeye tuna (Thunnus obesus) and admixture around South Africa. Mol Ecol 9:221-227

Clark TB, Ma L, Saillant E, Gold JR (2004) Microsatellite DNA markers for population-genetic studies of Atlantic bluefin tuna (Thunnus thynnus thynnus) and other species of genus Thunnus. Mol Ecol Notes 4:70-73

Collette BB, Carpenter KE, Polidoro BA, Juan-Jordá MJ and others (2011) High value and long life — double jeopardy for tunas and billfishes. Science 333:291-292

Davies CA, Gosling EM, Was A, Brohpy D, Tysklind N (2011) Microsatellite analysis of albacore tuna (Thunnus alalunga): genetic structure in the North-East Atlantic Ocean and Mediterranean Sea. Mar Biol 158:2727-2740

> DeWoody JA, Avise JC (2000) Microsatellite variation in marine, freshwater and anadromous fishes compared with other animals. J Fish Biol 56:461-473

Durand JD, Collet A, Chow S, Guinand B, Borsa P (2005) Nuclear and mitochondrial DNA markers indicated unidirectional gene flow of Indo-Pacific to Atlantic bigeye tuna (Thunnus obesus) populations, and their admixture off southern Africa. Mar Biol 147:313-322

Excoffier L, Smouse PE, Quattro JM (1992) Analysis of molecular variance inferred from metric distances among DNA haplotypes: application to human mitochondrial DNA restriction data. Genetics 131:479-491

Excoffier L, Laval G, Schneider S (2005) Arlequin ver. 3.0: an integrated software package for population genetics data analysis. Evol Bioinform Online 1:47-50

Fonteneau A, Soubrier P (1996) Interactions between tuna fisheries: a global review with specific examples from the Atlantic Ocean. FAO Fish Tech Pap 365:84-123

- Goñi N, Logan J, Arrizabalaga H, Jarry M, Lutcavage M (2011) Variability of albacore (Thunnus alalunga) diet in 
the Northeast Atlantic and Mediterranean Sea. Mar Biol 158:1057-1073

González EG, Beerli P, Zardoya R (2008) Genetic structuring and migration patterns of Atlantic bigeye tuna, Thunnus obesus (Lowe, 1839). BMC Evol Biol 8:252

Goudet J (2001) FSTAT, a program to estimate and test gene diversities and fixation indices (version 2.9.3). Available at: http://www2.unil.ch/popgen/softwares/fstat.htm

Graves JE, McDowell JR (1995) Inter-ocean genetic divergence of istiophorid billfishes. Mar Biol 122:193-203

Hardy OJ, Vekemans X (2002) SPAGeDi: a versatile computer program to analyse spatial genetic structure at the individual or population levels. Mol Ecol Notes 2:618-620

Hardy OJ, Charbonnel N, Fréville H, Heuertz M (2003) Microsatellite allele sizes: a simple test to assess their significance on genetic differentiation. Genetics 163: $1467-1482$

ICCAT (International Commission for the Conservation of Atlantic Tunas) (2010) Chapter 2: Description of species. ICCAT Manual, 1st edn. ICCAT, Madrid

Jakobsson M, Rosenberg NA (2007) CLUMPP: a cluster matching and permutation program for dealing with label switching and multimodality in analysis of population structure. Bioinformatics 23:1801-1806

Joseph J, Klawe W, Murphy P (1988) Tuna and billfish—fish without a country. Inter-American Tropical Tuna Commission, La Jolla, CA

> Knutsen H, Olsen EM, Jorde PE, Espeland SH, Andre C, Stensteth NC (2011) Are low but statistically significant levels of genetic differentiation in marine fishes 'biologically meaningful'? A case study of coastal Atlantic cod. Mol Ecol 20:768-783

> McDowell J, Diaz-Jaimes P, Graves JE (2002) Isolation and characterization of seven tetranucleotide microsatellite loci form Atlantic northern bluefin tuna Thunnus thynnus thynnus. Mol Ecol Notes 2:214-216

Megalofonou P (2000) Age and growth of Mediterranean albacore. J Fish Biol 57:700-715

Morita S (1977) On the relationship between the albacore stocks of the South Atlantic and Indian Oceans. Collect Vol Sci Pap ICCAT 7:232-237

> Nakadate M, Viñas J, Corriero A, Clarke S, Suzuki N, Chow S (2005) Genetic isolation between Atlantic and Mediterranean albacore populations inferred from mitochondrial and nuclear DNA markers. J Fish Biol 66:1545-1557

Nielsen EE, Hemmer-Hansen J, Larsen PF, Bekkevold D (2009) Population genomics of marine fishes: identifying adaptive variation in space and time. Mol Ecol 18: 3128-3150

O'Connell M, Wright JM (1997) Microsatellite DNA in fishes. Rev Fish Biol Fish 7:331-363

Oleksiak MF (2010) Genomic approaches with natural fish populations. J Fish Biol 76:1067-1093

Petit E, Balloux F, Goudet J (2001) Sex-biased dispersal in a

Editorial responsibility: Hans Heinrich Janssen, Oldendorf/Luhe, Germany migratory bat: a characterization using sex-specific demographic parameters. Evolution 55:635-640

Poulsen NA, Nielsen EE, Schierup MH, Loeschcke V, Gronkjaer P (2006) Long-term stability and effective population size in North Sea and Baltic Sea cod (Gadus morhua). Mol Ecol 15:321-331

Pritchard JK, Stephens M, Donnelly P (2000) Inference of population structure using multilocus genotype data. Genetics 155:945-959

> Pujolar JM, Roldán MI, Pla C (2003) Genetic analysis of tuna populations, Thunnus thynnus thynnus and T. alalunga. Mar Biol 143:613-621

> Riccioni G, Landi M, Ferrara G, Milano I and others (2010) Spatio-temporal population structuring and genetic diversity retention in depleted Atlantic bluefin tuna of the Mediterranean Sea. Proc Natl Acad Sci USA 107: 2102-2107

Rosenberg NA (2004) Distruct: a program for the graphical display of population structure. Mol Ecol Notes 4: $137-138$

Rousset F (2008) Genepop'007: a complete reimplementation of the Genepop software for Windows and Linux. Mol Ecol Resour 8:103-106

Santiago J (2004) Dinámica de la población de atún blanco (Thunnus alalunga Bonaterre 1788) del Atlántico Norte. PhD thesis, University of Basque Country, Euskal Herriko Unibertsitatea, Leioa

Takagi M, Okamura T, Chow S, Taniguchi N (1999) PCR primers for microsatellite loci in tuna species of the genus Thunnus and its application for population genetic study. Fish Sci 65:571-576

Takagi M, Okamura T, Chow S, Taniguchi N (2001) Preliminary study of albacore (Thunnus alalunga) stock differentiation inferred from microsatellite DNA analysis. Fish Bull 99:697-701

Viñas J, Santiago J, Pla C (1999) Genetic characterisation and Atlantic Mediterranean stock structure of albacore, Thunnus alalunga. Collect Vol Sci Pap ICCAT 49: 188-190

Viñas J, Alvarado Bremer JR, Pla C (2004) Inter-oceanic genetic differentiation among albacore (Thunnus alalunga) populations. Mar Biol 145:225-232

- Weir BS, Cockerham CC (1984) Estimating F statistics for the analysis of population structure. Evolution 38: 1358-1370

Wu GCC, Chian HC, Chen KS, Hsu CC, Yang HY (2009) Population structure of albacore (Thunnus alalunga) in the Northwestern Pacific Ocean inferred from mitochondrial DNA. Fish Res 95:125-131

Yeh SY, Treng TD, Hui CF, Penney AJ (1997) Mitochondrial DNA sequence analysis on albacore, Thunnus alalunga, meat samples collected from the waters off western South Africa and the eastern Indian Ocean. Collect Vol Sci Pap ICCAT 46:152-159

Submitted: June 15, 2011; Accepted: August 8, 2012

Proofs received from author(s): November 30, 2012 